\title{
Assessment of biomarkers in Mytilus edulis to determine Good Environmental Status for implementation of MSFD in Ireland
}

Giltrap, M. ${ }^{a^{*}}$, Ronan, J. ${ }^{\text {a, }}$, Hardenberg, S. ${ }^{\text {a }}$, Parkes, G. ${ }^{\text {a }}$, McHugh, B. ${ }^{\text {b }}$, McGovern, E. ${ }^{\text {b }}$, Wilson, J.G. ${ }^{\text {a }}$

a'Zoology Department, Trinity College Dublin, Dublin 2.

${ }^{\mathrm{b}}$ Marine Institute, Rinville, Oranmore, Co. Galway

*Corresponding author: giltrapm@tcd.ie

\begin{abstract}
Candidate OSPAR/ICES recommended biomarkers at the level of the individual in Mytilus edulis for determination of good environmental status for MSFD were evaluated against contaminant levels at sites around Ireland. The sites chosen ranged from moderate to low pollution levels, but the actual ranking of the sites varied according to the contaminant levels present. At the most contaminated site, Cork, 4 out of 16 contaminants exceeded the EAC, while at Shannon, no EACs were exceeded. The SOS assay suggested that Cork was the healthiest site with a LT $_{50}$ of 17.6 days, while SOS for Shannon was 15.6 days. Likewise, condition factors varied among sites and did not always correspond to contaminant-based status. There may be uncertainty in assigning status around the not good:good boundary. This raises potential difficulties not only in the biomarker/contaminant load relationship but also in the reliability of the biomarkers themselves and hence barriers meeting compliance levels.
\end{abstract}

Keywords: OSPAR; ICES; MSFD compliance; Mytilus edulis; Biomarkers; contaminants; 


\subsection{Introduction}

The main objective of the Marine Strategy Framework Directive (MSFD) [2008/56/EC] is to maintain good environmental status for marine waters, habitats and resources delivered in an integrated ecosystem based approach. In general current water quality assessments for hazardous substances in Ireland and elsewhere relied solely on chemical analysis alone but it is widely accepted through the Oslo and Paris Commission (OSPAR) and the International Council for Exploration of the Sea (ICES) that chemical monitoring alone is no longer sufficient to assess pollution impacts in the marine environment and that integration of chemical and biological effects data is essential to provide an insight into the actual health status of the ecosystem. In recent years OSPAR and ICES have increased their focus on the integration of biological and chemical data, this being a key reporting requirement under the MSFD (8.2). Integration of such measurements forms an important element in linking contaminants and ecological responses and in assessing the overall quality of the marine environment. Over the last few years a wide range of biomarkers have been employed in monitoring to provide early warning signals for potential contamination.

The blue mussel, Mytilus edulis has been extensively used as an indicator of environmental pollution due to its sedentary and filterfeeding nature and its ability to accumulate chemical contaminants from the seawater, from resuspended sediment, and from particulate food material (Moore et al., 2004). The Mussel watch concept, first proposed by Goldberg (1975) has been adopted by many countries including Ireland whereby mussels are used as sentinel organisms of contaminant exposure. As well as contaminant detection in tissues, a range of biomarkers can be used in order to assess impacts on the individual mussel. As part of the ecosystem based approach, an integrated assessment strategy for mussels (Thain et al., 2008) has been put forward by the ICES Working Group on Biological Effects of Contaminants (WGBEC). This strategy promotes monitoring multiple responses in the blue mussel at several levels including whole organism, tissue, subcellular and tissue chemistry. Biomarkers that are used to monitor the health status of an animal are termed biomarkers of toxic effects and are biological changes that can be attributed to a cumulative effect of stressors in the environment rather than one type contaminant (biomarker of exposure). In the present study two whole organism biomarkers of toxic effects are assessed, namely stress on stress and scope for growth along with its components clearance rate and respiration rate. Both methods are included as techniques (SFG optional) for integrated monitoring using mussels as indicators and are put forward by the ICES WGBEC group. These whole organism responses are near the top level of organization and have high relevance as biomarkers.

Scope for growth has been used as a sensitive response to detect and quantify sublethal effects of both laboratory exposed contaminants including oils, PAHs, alkyltins, metals, (Widdows et al. 1987; Moore et al., 1984; Widdows and Page 1993) and insitu field exposure of contaminants mainly in marine mussels (Mytilus spp.). Studies in the field have mainly utilised a combined approach and linked chemical concentrations to SFG effects in many locations in and around harbours, near sewage outfalls, bays, lagoons and the Irish Sea (Halldórsson et al., 2005; Anderlini, 1992; Widdows et al., 1980-81, 1997 and 2002). Clearance rate in mussels has been used as an individual biomarker and in combination with SFG to evaluate the effects of contaminants such as 
tributyltin and dibutyltin, interactive and individual effects of copper and phenanthrene (Widdows and Page, 1993; Moore et al., 1984) and used on its own to evaluate combined effects of alkanes and aromatic hydrocarbons, complex mixtures of petroleum hydrocarbons and copper, hydrophobic organic toxicants such as naphthalene (Widdows et al., 1989) and mercury chloride (Duchemin et al., 2008). SFG responses in Mytilus edulis have been reported at hot spot locations such as harbours in Iceland (Halldórsson et al. 2005). Previous studies have shown that a decline in SFG indicating poor performance and physiological condition was linked to increasing levels of pollution (Widdows et al. 1980; 2002; Halldórsson et al. 2005).Widdows et al. 2002 reported the impact of pollution using scope for growth as an indicator along the Irish Sea including Dublin Bay and Duncannon in Wexford. The authors reported a decreasing trend in SFG linked to elevated levels of contaminants in Dublin Bay and to a lesser extent in Wexford.

Condition factor (CF) is a measure that has been previously used to assess the condition of organisms and has been used in combination with other indices such as respiration rate (Wilson and McMahon, 1981). Individuals may have a higher gross weight at a particular length during times of high food intake and at particular stages of the gametogenic cycle and therefore the condition of the animal can demonstrate changes in normal condition due to other external environmental factors. This can be assessed by calculating the coefficient of condition (K) or by Fulton's condition factor (Bagenal and Tesch, 1978) which has mainly been used in fish studies. Condition factor is used in the present study as a general marker of stress.

Another biomarker, stress on stress (SOS), also known as "survival in air" measures the ability of mussels to survive periods of air exposure. Stress on stress has been used previously as a sensitive response to effects of xenobiotics, including heavy metals, organometals and organics (Viarengo et al., 1995; Eertman et al., 1993; Smaal et al., 1991; Hellou and Law, 2003) as well as contaminated field sediments (De Zwaan and Eertman, 1996). De Zwaan et al. (1996) reported that metabolic arrest which is an important mechanism involved in the survival under anoxic conditions, can be compromised when organisms are dealing with contaminant burden. In intertidal mussels, consumption of oxygen while exposed to air is a natural mechanism whereas subtidal mussels don't consume oxygen at all when suddenly exposed to air (De Zwaan et al., 1996). The intertidal mussel will have a high oxygen demand and mainly use aerobic metabolism (efficient) where oxygen consumption may account for $40 \%$ of total metabolic heat dissipation. Subtidal mussels will be deprived of oxygen and therefore have lower oxygen demands and switch from aerobic to anerobic metabolism. Under anerobic conditions, glycogen is the main source of energy and much less efficient than the aerobic source of glycogen. Pampanin et al. (2005) reported longer survival times from mussels collected above the water level compared to below. The $\mathrm{LT}_{50}$ measured (time at which $50 \%$ of the animals have died) compares well with stress indices at the cellular level (Viarengo et al. 1995).

In general, Ireland's coastal waters have generally good quality (McGovern et al., 2011) with low levels of persistent contaminants (Hartnett et al., 2011) and so this provides good testing ground for biomarker sensitivity at control/reference boundaries of 
contaminants. This study aims to investigate how well the recommended ICES/OSPAR candidate biomarkers link with contaminant data in the Irish marine environment. 


\subsection{Materials and Methods}

\subsection{Site selection and sampling}

Nine sites around Ireland were selected for biological and chemical monitoring of Mytilus edulis. These potentially impacted/non impacted sites were chosen on the basis of historical data. The basis of selection including potential pressures and literature review of sites is outlined in Table 1. Sampling and measurements were carried out in the autumn of 2009 and 2010 after the main spawning period of the mussels. Two potentially "clean" reference locations were selected on the West coast of Ireland namely Galway (Lettermullen) and Shannon estuary as marine and estuarine controls respectively while Newquay was selected as a subtidal marine control. In addition to this, six other sites were selected along a gradient of predicted pollution of which Dublin Bay was predicted highest, Cork Harbour (Ringaskiddy), Tralee Bay, Kinvarra Bay, Wexford Harbour, and Bantry Town. Mussels were sampled randomly at mid shore level from each mussel bed area. Overall, two hundred mussels were sampled per site of which 20 (40-45mm SL) for SFG and $50(50-60 \mathrm{~mm})$ for SOS were taken. In addition to this an extra 45 mussels (55-60 mm) were sampled for other biomarker analyses including condition factor. Temperature, salinity and substrate were noted for each site. The mussels were then placed into insulated containers and transported back to the laboratory on ice packs covered in seaweed gathered from the site. All mussels were cleaned and allowed to flush sediment and gut contents for one hour in aerated filtered seawater (ca. 51 for 20 mussels). After this mussels were left to acclimatise overnight in filtered seawater (ca. 201 for $24 \mathrm{hrs}$ for 20 mussels). Mussels were kept in filtered seawater with water renewed after the first $24 \mathrm{hrs}$ (ca. 201 for $24 \mathrm{hrs}$ for 20 mussels) and any spawning mussels were removed from aquaria.

\subsection{Scope for Growth (SFG)}

For SFG measurements, seawater was sourced from a site outside Dublin Bay beyond Kish bank (GPS: 53 $18^{\prime}$ 37. 95” N, $005^{\circ}$ 55' 36. 76"W) at high salinity (> $33 \mathrm{ppt}$ ) and was filtered through a $1 \mu \mathrm{m}$ filter in order to remove particles. The procedure for SFG including clearance rate, and respiration rate was carried out using a static system according to the ICES protocol by Widdows and Staff (2006) with the following minor modifications. In total, 13 mussels were used for the SFG experiment $(12+1$ control). Absorption efficiency of the mussels was not measured. Instead an absorption efficiency of 0.5 and standardised food concentration (food energy value) of $10 \mathrm{JL}^{-1}$ were used in calculations of SFG (Widdows and Staff, 1997).

\subsection{Stress on Stress (survival in air assay)}

After the overnight acclimatisation period, the mussels were placed on a labeled tray at $15{ }^{\circ} \mathrm{C}$ with $12 \mathrm{~h}$ of light and dark. Mussels were checked daily for mortalities. Open valves were checked for response by tapping if after one minute the mussel had not closed or attempted to close, it was deemed to be dead.

\subsection{Condition Factor}


The length (cm), flesh dry weight (g) (SFG only) and flesh wet weight (g) was recorded and the condition index was calculated using Fulton's condition index as follows: $\mathrm{CF}=$ wet weight/(shell length $)^{3} * 100$.

\subsection{Chemical analysis}

2.5.1 Chemical methodology for tissue analysis

Metals analysis was completed under contract by LGC, Middlesex, United Kingdom. Samples (0.5g) were microwave digested in 7 $\mathrm{mls}$ of concentrated nitric acid and $3 \mathrm{mls}$ of hydrogen peroxide. Sample digests were diluted to $50 \mathrm{mls}$ with water prior to analysis by ICP-MS. Quantification was completed by external calibration with standards prepared in the same diluents as the samples.

Polychlorinated biphenyls (PCBs) and organochlorine pesticides (OCPs). Due to the lipophilic nature of PCBs and OCPs, lipid was extracted from tissue using the method developed by Smedes (Smedes, 1999). Chlorinated hydrocarbons were removed from the lipids by alumina column chromatography, followed by separation of PCBs from the chlorinated pesticides using silica column chromatography. Concentration levels were determined by dual column Gas Chromatography with Electron Capture Detection (GCECD), using a Varian 3800 gas chromatograph fitted with a 60 metre fused silica capillary column (HT8, J and W Scientific). A second column of different polarity was used as confirmation (CP-SIL 19CB, Chrompack Varian Inc).

Polycyclic aromatic hydrocarbon (PAH) analysis was completed under contract by Eurofins, Munster Germany, on freeze dried mussel tissue spiked with a mix of deuterated internal standards. Extraction was completed by cold liquid/liquid with Acetone/Hexane followed by a clean-up using silica gel column chromatography. Analysis was performed with HRGC/HRMS (60m HP5ms-type column; Thermo DFSHRMS) and using the isotope dilution technique.

For all completed analysis full quality assurance appropriate to the individual test was completed, including use of matrix matched internal reference materials alongside with sample batches for long term monitoring of the analytical performance. All laboratories are successful participants in international proficiency exercises relevant to suite of parameters.

\subsubsection{Contaminant ranking using scores based on relationship to assessment criteria (AC) per site.}

For assessment, OSPAR AC was used including background assessment criteria (BAC) and ecotoxicological assessment criteria (EAC). For metals, European Commission maximum concentrations in foodstuffs to protect public health values (EC) are used. These 
are set out in Commission Regulation no 1881/2006. For ranking, dry weight normalised values were used for comparison to assessment criteria. Only contaminants where AC was available were used for assessment including CB28, CB52, CB118, CB153, CB138, CB180, benzo-(a)-anthracene, benzo-(a)- pyrene, benzo-(ghi)-perylene, fluoranthene, phenanthrene, pyrene, cadmium, mercury and lead. Some contaminants such as $\alpha-\mathrm{HCH}$ did have a derived BAC however these were not included in this present assessment. Only scores were derived for contaminants for which EACs/ECs are available. A score for each contaminant at each site was calculated by how many times it exceeded the EAC/EC. This value was multiplied by a factor of 100 . The parameter which exceeded the EAC to the greatest degree with was designated a score of "10", with other site/sample scores assigned a pro-rata score relative to the highest one. Finally a score was created for each individual contaminant, groups of contaminants such as PCBs, PAHs and metals component and an overall score for the sample/site was obtained by using a method described by Damiens et al., (2007) as follows $\left.\left[\left(\mathrm{B}_{1} \times \mathrm{B}_{2}\right) / 2\right]+\left[\left(\mathrm{B}_{2} \times \mathrm{B}_{3}\right) / 2\right]+\ldots\left[\left(\mathrm{B}_{n-1} \times \mathrm{B}_{\mathrm{n}}\right) / 2\right]+\left[\left(\mathrm{B}_{\mathrm{n}} \times \mathrm{B}_{1}\right) / 2\right]\right\}$ where $\mathrm{B}_{1}, \mathrm{~B}_{2} \ldots \mathrm{Bn}$ are the derived scores for the contaminants and divided by $\mathrm{n}$ parameters.

\subsubsection{Ranking procedure for biomarkers}

For the biomarker ranking, SFG, CR, RR, SOS and CF were used to evaluate sites. The most impacted site for each parameter was given a score of 10 and other sites were assigned pro rata scores to this. Final scores were then alculated by using Damiens et al., (2007) method as above and scores/n parameters were ranked. The higher the ranked number for each site, the closer it is to background for both contaminants and biomarkers.

\subsection{Statistics}

Statistical analysis of the data was completed using the computer program R 2.14.2. A Wilcoxon Rank Sum test was performed in order to detect significant differences amongst potential impacted and control groups with SFG, CR, RR and CF. A Kruskal-Wallis test with post hoc non parametric multiple comparisons (using multiple Behrens Fisher test) was performed in order to detect which sites were different to each control for each of these assays. Freidman's two way analysis of variance (Siegel, 1956) was also performed on the data to check for significant differences. Correlations were performed in S-PLUS with contaminants and bio effects data to check for significant positive and negative correlations using Pearson coefficient. A correlation permutation test (Whitehead, 2008) was applied to SFG and stress on stress in order to test for significant correlations between both SFG and SOS physiological assays. For the SOS assay, \% mortality data were fitted to a sigmoidal curve and a four parameter logistic model was used to calculate the $\mathrm{LT}_{50}$. The $\mathrm{LT}_{50}$ values are reported $\pm 95 \%$ confidence intervals $( \pm 95 \% \mathrm{CI})$. One replicate per site was obtained and the CI was based on this. All sigmoidal curves had $\mathrm{R}^{2}$ significant at $\mathrm{p}<<0.001$. This analysis was performed using Xlfit3TM, a curve fitting addin for Microsoft1 Excel (ID Business Solutions). Data were also analysed with PRIMER 6 and PERMANOVA + package BEST routine using the BIOENV routine (full search for all possible combinations of the variables). Non normalised, wet weight values of contaminant environmental data (PCB153,pp-DDE, BFR47, chromium, nickel, copper, zinc, arsenic, silver, cadmium, mercury, lead, 
salinity and water temperature) and biological effects data were used for the BEST analysis. All PRIMER data were normalised where appropriate and standardized and then transformed. All data was classed as environmental and analysed with eluclidean distance. 


\subsection{Results}

\subsection{Contaminant data}

Contaminant data $\left(\mu \mathrm{g} \mathrm{kg}^{-1} \mathrm{dw}\right)$ as well as associated assessment criteria is presented in Table 2 . The overall contaminant and breakdown of its components scores (PCBs, PAHs and metals) and biomarker scores are outlined in Table 3 as well as comparative ranking of sites. Galway was not included in the contaminant ranking as no contaminant data was available for this site. An overall mean ranking was calculated between biomarkers, between contaminants and between both biomarkers and contaminants.

\subsection{Environmental and contaminant data and correlations with bio effects}

Temperature and salinity data for the nine sites are presented in Table 4. Multiple correlations were performed in S-PLUS for all biological effects data, contaminant and environmental data (salinity and temperature), With the biological effects data, dry weight of the animal showed significant negative correlations with CR, consumption (C), assimilation (A), and SFG (-0.65 to -0.88). A positive correlation was detected with dry weight and condition (0.86). Significant negative correlations were observed for condition and CR, C, A and SFG (-0.65 to -0.88) and significant positive correlations for water temperature for the same parameters (0.7 to 0.9). Also water temperature was negatively correlated with condition (-0.71). Respiration was positively correlated with water temperature (0.74). There were significant negative correlations with salinity and p,p-DDE (-0.92), CB180 (-0.82), HCB (-0.82) and BFR-28(0.87). Significant correlations were detected with $\mathrm{LT}_{50}$ and $\alpha-\mathrm{HCH}(0.80)$, lindane (0.88), cadmium (0.89) and mercury (0.95). There were positive correlations observed with heptachlor and CR, C, A and respiration (0.83-0.92). SFG was positively correlated with $\alpha-$ $\mathrm{HCH}$ (0.92). Concentration data for p,p-DDE, HCB, BFR-28, $\alpha-\mathrm{HCH}$, lindane and heptachlor are not shown.

\subsection{Scope for growth}

The results for scope for growth including clearance rate, respiration rate $\left(\mathrm{J} \mathrm{h}^{-1} \mathrm{~g}^{-1}\right)$ and food absorption efficiency as well as dry weights and shell length are presented in Table 5. Scope for growth data showed a significant difference ( $p<<0.001)$ between grouped control (Shannon and Galway) and grouped other sites. When separated and tested Wexford, Bantry and Newquay had significantly lower SFG to the control site Galway and Dublin showed significantly lowered SFG than Shannon. The sites demonstrated the following order of decline in SFG, Galway $>$ Shannon $>$ Bantry $>$ Wexford $>$ Dublin $>$ Newquay. Clearance rates $\left(L h^{-}\right.$ ${ }^{1}$ animal $^{-1}$ ) (Table 5 and Figure 1(a) demonstrated grouped controls were significantly different to potentially impacted sites [W $=551$, p-value $=0.002]$ but when tested there was no significant differences between any single pair of sites. The order of increasing stress for the sites for CR $\left(\mathrm{L} \mathrm{h}^{-1}\right.$ animal $\left.^{-1}\right)$ was found to beTralee $<$ Galway $<$ Shannon $<$ Bantry $<$ Newquay $<$ Kinvarra $<$ Dublin $<$ Cork $<$ Wexford. For weight specific CR $\left(\mathrm{L} \mathrm{h}^{-1} \mathrm{~g}^{-1}\right)$ shown in Figure 1(a) and (b) there was a significant difference between grouped impacted and control sites [W $=386, \mathrm{p}<<0.001]$. When separated and tested Dublin and Kinvarra had significantly lower clearance rates than Shannon. Kinvarra was also significantly lower than Galway while Newquay was significantly lower than Tralee. Respiration rates (Table 5) show no significant difference detected between grouped control and grouped other sites [W = 597, p 0.38]. Bantry, Dublin 
and Newquay showed significantly higher respiration rates than Galway while Wexford mussels showed significantly lower respiration rates than Galway, Shannon and Newquay. Dublin was also significantly lower than Newquay. The order of decreasing respiration rates indicating increased sensitivity was Newquay $>$ Shannon $>$ Bantry $>$ Dublin $>$ Galway $>$ Wexford. Statistical significance amongst sites for SFG, CR and RR are displayed in Table 5. Assessment criteria for SFG are displayed in Table 5. For assessment purposes the SFG mean $+95 \%$ confidence interval was used to compare to AC. Galway was determined to be below BAC (at background) while all other sites were above BAC but below EAC. This data is displayed in Figure 2.

\subsection{Stress on stress}

The SOS assay results and assessment criteria are presented in Table 6. All sites were below the EAC with most sites demonstrating the $\mathrm{LT}_{50}$ to be below BAC. The order of decreasing health was as follows: Cork $>$ Shannon $>$ Dublin $>$ Kinvarra $>$ Galway $>$ Tralee $>$ Newquay $>$ Wexford. A correlation permutation test (Whitehead, 2008) was applied to SFG and SOS data indicating a significant $(\mathrm{p}=-0.034)$ negative relationship between SFG and SOS. Therefore this creates a basis for use of the SOS assay as an alternative to the SFG assay in future studies.

\subsection{Conditon factor}

Condition factors for all sites are presented in Table 4. For condition factor grouped controls were not found to be significantly different to potentially impacted sites overall $[\mathrm{W}=1223, \mathrm{p}=0.07]$. There were significant differences among individual sites $\mathrm{p}<<$ 0.001. Dublin, Cork and Kinvarra were all found to have significantly higher condition compared to Galway. Bantry, Cork, Galway, Newquay and Shannon all showed to have a significantly higher condition factor than Tralee Bay. 


\subsection{Discussion}

Assessment criteria were used to confirm if contaminants were present at levels that would potentially cause an effect in the organism. This was done with the use of comparison to BAC /EAC values and a ranking system. Overall when comparing all sites monitored for SFG, SOS, CF and contaminant data, most results were not in agreement with each other. SFG in Newquay mussels demonstrated them to have a response very close to EAC while contaminant data showed all contaminants assessed being below EAC at this site. SOS response was below EAC at all nine sites monitored however with the contaminant data, three sites had contaminant levels that were above EAC namely Cork with PCB28, PCB52, PCB118, Dublin with PCB 101 and PCB118 and Bantry with PCB 118. In fact, Cork showed to be the healthiest site with the SOS assay and ranked most impacted with the contaminant data. This is evident in the ranking of the sites where Cork showed to rank with lowest effects (8) with the biomarkers and most contaminated (1) with the contaminant ranking (Table 3). The opposite was observed for Wexford ranking as 6 with contaminants and 1 with biomarkers. Wexford harbour showed to be the most impacted site with SFG, SOS, CR, RR demonstrating stressed animals at this site however the contaminant data did not reveal the same with Wexford showing low levels of contaminants with none above EAC for this site. In addition to this, Wexford mussels had the highest condition factor compared to all sites (Table 4). Shannon proved to be the most promising for use as a control site with SOS, SFG RR, CR and contaminant data. At the Shannon site SFG was above BAC but below EAC and SOS showed to be below BAC. The ranking methodology used in this study proved quite useful and truly interpreted the data for both the contaminants levels and biomarker effects. Also the use of the contaminant grouping scores (PCBs, PAHs, metals etc.) gave more insight into the attributed rank.

It is possible that other parameters which are possibly causing natural or anthropogenic stress were not accounted for in this study but are affecting the organism. For example tributyltin (TBT) was not monitored in the mussels in the present study and it is possible that this contaminant could have attributed to the effects if present. Cork harbour does have a history of TBT contamination (Minchin et al., 1996) and recent analyses indicate a high level of imposex in dogwhelks sampled from the Ringaskiddy site (Wilson et al. in preparation). Cork has the highest $\mathrm{LT}_{50}$ with the SOS assay. It is therefore likely that the mussels at this site have become acclimatised to the pollution levels. For other sites such as Wexford where no EACs were exceeded, it is possible that other anthropogenic influences attributed to the effects on the organisms.

Condition factor was used in this study as a supporting parameter in relation to other biological effect measurements. Dublin, Cork and Kinvarra were all found to have significantly higher condition compared to Galway. Bantry, Cork, Galway, Newquay and Shannon all showed to have a significantly higher condition factor than Tralee Bay. Tralee Bay did have a high prevalence of both male and female pea crabs (\% prevalence). At all other sites there were no incidences of these parasites. Incidence of pea crab (Pinnotheres ostreum) has previously been reported to have an effect on the eastern oysters (Crassostrea virginica) reproductive capability and overall condition and that the pea crab/oyster relationship is a parasitic one (O'Beirn and Walker, 1999). This could account for the low condition in Tralee Bay mussels. 
Mean scope for growth results in this study for Dublin and Wexford were determined to be 4.38 and $4.75 \mathrm{~J} \mathrm{~g}^{-1} \mathrm{~h}^{-1}$ respectively and were comparable to that of the Widdows et al. (2002) study $\left(<5 \mathrm{~J} \mathrm{~g}^{-1} \mathrm{~h}^{-1}\right)$ for both sites. Widdows et al. (2002) performed a quantitative toxicological interpretation based on quantitative structure activity relationships (QSARS) of the combined tissue chemistry and SFG measurements indicating declines in SFG attributed to specific types of pollution sources of contamination and calculated that a large proportion of reduced SFG for Dublin and Wexford was attributed to sewage pollution in the areas. Outputs of sewage have also been found to be the main contributor to reduced SFG in Mytilus edulis from New Zealand (Anderlini, 1992). Galway and Shannon were determined to be the least stressed mussels with the SFG assay. Assessment criteria for SFG demonstrated Galway to be at background while the rest were below EAC but above BAC. Newquay Wexford and Dublin all had substantially lower SFG values than Shannon and Galway. Newquay was also determined to have a lower survival in air compared to the reference locations which was an unexpected result however this could be due to these mussels being subtidal and unable to cope very well with prolonged periods of air exposure during transport compared to the other mussels which were all intertidal. Mytilus species have a controlled response in air and therefore have a reduced metabolic demand. Tidal exposure to air results in metabolic stress through the inability to feed, a limit to gas exchange and exposure to desiccation and can therefore reduce scope for growth especially in subtidal mussels whereas intertidal mussels would be more adapted. Both Dublin Bay and Wexford harbour are classed as problem areas under the OSPAR Common Procedure for nutrient enrichment effects. In addition to this both sites with Dublin in particular would have a lot of anthropogenic influences including shipping, industry, sewage outfall pipes, agricultural run off from the rivers Tolka, Liffey and Dodder in Dublin and the Slaney in Wexford. Bantry was observed to be healthier for SFG. Outer Bantry Bay has a history of TBT, metal and hydrocarbon contamination (Enterprise Ireland, unpublished data). However Bantry mussels were taken from the harbour walls and therefore higher on the shoreline compared to other areas (mid shoreline) and therefore would be expected to have higher respiration and clearance rates and this could account for the higher values in SFG.

Anderlini, 1992 reported that the presence of additional unknown toxicants also attributed to reduced SFG and identified linear alkylbenzenes and arsenic as important influences. A highly significant arsenic correlation with SFG is reported in this present study. Interestingly, SFG was significantly correlated with $\alpha-\mathrm{HCH}$ also with highest levels (below BAC) observed in Shannon $(0.347 \mu \mathrm{g} / \mathrm{g}$ ). The water temperature and salinity at each of the respective sites varied greatly however salinity and temperature probes for these sites would need to be monitored long term in order to assess maximum and minimum values to be more accurate. A positive relationship between metal uptake and temperature has been reported meaning that different temperatures could affect SFG measurements specifically in relation to contaminants (Mubiana and Blust, 2007). In the present study, a positive correlation was observed between respiration and water temperature. The stage of gametogenic cycle has also been found to be of high significance and can add to reduced scope for growth (Widdows et al., 1980-81). Gametogenic cycle can vary geographically and also in relation to the position of the mussels on the shoreline and influence of other variables. For the present study, time of year of sampling was controlled assuming 
the same gametogenic condition however this was not always the case and it was found that gametogenic cycle varied between animals at the sites studied (unpublished data).

Respiration rate has also been used as a sublethal physiological response in combination with SFG for evaluation of toxicants such as alkyltins (Widdows and Page 1993) and other toxic substances such as benzene, phenol and formaldehyde (Nordtug et al., 1991). Wilson and McMahon 1981 reported measurements of Mytilus edulis at sites at different distances from a copper laden estuary. Respiration rates for the six sites measured indicated a different sequence of impacted sites from SFG with Newquay and Shannon having the highest respiration rates and Galway and Wexford having quite low respiration rates. Overall Wexford had the lowest respiration rate and demonstrated to be the most impacted site and Newquay the healthiest. Wilson and McMahon (1981) reported oxygen consumption ranges between $0.290-0.454 \mu \mathrm{mg}^{-1} \mathrm{hr}^{-1}$ in Mytilus edulis along a copper laden estuary, but these values did not vary significantly with copper concentration however Manley (1983) reported a significant reduction of 58.3\% in the oxygen consumption after exposure to $0.2 \mathrm{ppm}$ copper. Both Wexford and Shannon showed similar levels of copper in this study (6749 and $6985 \mu \mathrm{g} \mathrm{g}^{-1}$ respectively). Dublin also showed to be significantly lower than Shannon. Dublin had the most elevated level of copper $\left(10859 \mathrm{\mu g} \mathrm{g}^{-1}\right)$ compared to other sites. Bantry, Dublin and Newquay were all significantly higher than Galway which was unexpected however Bantry mussels were taken from higher on the shoreline than the other sites. Mussels have different capacities for survival on different parts of the shore. The height at which individuals are located on the shore can affect their respiration rates when immersed. Also, intertidal mussels have a high tolerance to anoxia when exposed compared to subtidal mussels. Moon and Pritchard (1970) have demonstrated that the rate of oxygen consumption by $M$. californianus was greater in individuals higher on the shore than individuals lower on the shore. In the same study, high shore animals also showed greater increase in respiration rate after periods of air exposure than did the low shore individuals. It was expected that Newquay mussels, being subtidal would have had a lower respiration rate than reported but this was not so and could be related to other environmental variables present. Using BEST analysis (Table 7) it was demonstrated that temperature was one of the predictor variables which best described $90.4 \%$ of the respiration rate data but this was not significant $(\mathrm{p}=0.31)$. Newell and Pye $(1970)$ reported that the rates of oxygen consumption are temperature dependent at all times of the year.

Hagger et al. (2008) also reported the use of clearance rate on its own for assessment of good ecological status in relation to the WFD with more pollutant impacted mussels demonstrating a lower clearance rate. For CR $1 \mathrm{~h}^{-1}$ animal ${ }^{-1}$, Shannon and Galway showed the highest CRs and Cork and Wexford the lowest however this was not significant. When corrected to dry weight, Tralee and Galway had the highest CRs and again Cork and Wexford were the most impacted sites. Dublin and Kinvarra had significantly lower CRs than Shannon. Tralee and Kinvarra mussels were sampled in close proximity to sewage outfall pipes (of which Kinvarra is untreated). Other factors such as salinity have been shown to effect filtration rate. Wang et al. (2011) reported decreasing clearance rate, absorption efficiency, respiration rate and scope for growth with decreased salinity in the green lipped mussel Perna viridis. This was evident in the data and it was demonstrated that salinity was one of the variables which best described the variation in data for CR $1 \mathrm{~h}^{-1}$ $\mathrm{g}^{-1}$ (see Table 5). Although there is no BAC/EAC developed for CR, Hagger et al. (2008) developed a classification for WFD quality 
assessments for $\mathrm{CR} 1 \mathrm{~h}^{-1}$ animal ${ }^{-1}$ [0-0.99=Severe pollution, 1-1.49=Major, 1.5-1.99=moderate and 2.0+= Slight.]. Using this classification, Wexford was the most impacted being in the severe pollution range and Dublin, Cork, Kinvarra, Newquay and Tralee were in the major polluted range while Galway, Shannon and Bantry were in the moderate range.

When compared to assessment criteria available, SOS showed all sites to be below EAC. The order of increasing stress was as follows: Cork $>$ Shannon $>$ Dublin $>$ Kinvarra $>$ Galway $>$ Bantry $>$ Tralee $>$ Newquay $>$ Wexford with Cork shown to be the least impacted site and Wexford the most impacted. Previous studies have shown that mussels exposed to contaminants utilise a great deal of energy for detoxification processes and have less tolerance to anoxic conditions (Viarengo et al. 1995; Eertman et al. 1993) and therefore do not survive as long in air as healthier unexposed mussels. Eertman et al. (1993) reported a reduction in survival in air in Mytilus edulis after 3-4 weeks exposure to $1 \mu \mathrm{g} \mathrm{l}^{-1}$ PCB. It is interesting that Cork had the highest $\mathrm{LT}_{50}$ while containing elevated levels of PCBs (PCB28, 52 and 118 above EAC) compared to other sites. Hellou and Law (2003) reported comparable values to this present study with LT $_{50}$ 's ranging from 3-14 days. Newquay had shorter survival times which could be because they are subtidal and less able to deal with aerial exposure stress. Tralee bay had quite a short survival time which was expected as this site had the highest level of cadmium $\left(2030 \mu \mathrm{g} \mathrm{g}^{-1}\right)$. It also had a high prevalence of pea crabs. These mussels therefore had multiple stressors both anthropogenic and natural and this could account for the lower survival time. Both the SOS response and cadmium level in Tralee mussels were below EAC but above BAC. Cork, Dublin and Kinvarra all showed increased survival times compared to Galway and this was also evident in the condition of the mussels from these sites where the sequence of decreasing condition was observed to be Kinvarra=Cork $>$ Wexford=Dublin $>$ Newquay $>$ Bantry $>$ Galway=Shannon $>$ Tralee. After applying a correlation permutation test (Whitehead, 2008) to both SFG and SOS data, a significantly negative relationship ( $\mathrm{p}=-0.034$ ) was detected between SFG and SOS. Therefore this creates a basis for use of the stress on stress assay as an alternative to the scope for growth assay in future studies.

\section{Conclusion}

The physiological responses measured in this present study prove that individuals from different sites with different levels of natural and anthropogenic stress had reduced capacity to adapt to further environmental changes and this resulted in reduced energy available for growth and reproduction with the SFG assay. However the same was not shown with the chemical analysis and therefore creates a mixed picture of the status of each site between biological effects and chemistry. It is possible that exposure to mixtures of pollutants created antagonistic effects in the mussels. It is clear from thisstudy that the biomarkers selected for determination of Good Environmental Status (GES) are indicating differences in relation to contaminant data. It is possible that other contaminants for example TBT and hydrocarbons which were not monitored in this study could also influence these effects and could be the culprit contaminants. It is also evident that certain types of stressors can have significant effects on certain parameters for example with cadmium and clearance rate, arsenic and SFG. Perhaps different biomarkers should be selected based on the potential of the stress of interest however further research would be required to confirm this. Biomarkers can deliver contradictory status evaluations and the 
relationship between biomarkers and contaminants can likewise contradict. Boundaries such as the BAC/EAC need to be continuously updated and reviewed. The disparity of status between biomarker and chemical data outlined in this study outlines the requirement for further investigations between relationships and development of AC. It is possible that problems shall arise upon integration of data at a higher level. However the ranking system used in this present study clearly portrayed the data and can be used as a functional tool for future monitoring. 


\section{Acknowledgements}

The authors would like to thank Dr. Colby Tanner of the Behavioural and Evolutionary Ecology Group, Zoology Department, Trinity College Dublin for conducting permutation tests in this study. 
Figure 1 Clearance rate $1 \mathrm{~h}^{-1}$ animal ${ }^{-1}$ and (b) clearance rate $1 \mathrm{~h}^{-1} \mathrm{~g}^{-1}$ for all nine sites with significant difference to control site Shannon $\mathrm{p}<0.05\left(^{*}\right), \mathrm{p}<0.001\left(^{* *}\right), \mathrm{p}<0.0001\left(^{* * *}\right)$ and significant difference to control site Galway $\mathrm{p}<0.05\left(\left(^{\dagger}\right), \mathrm{p}<0.001\left(^{\dagger \dagger}\right), \mathrm{p}<\right.$ $0.0001\left({ }^{\dagger \dagger}\right)$

Figure 2(a) Biological effects data (mean $+95 \%$ confidence interval) comparison to assessment criteria (BAC [ $\square]$ and EAC [ $\square]$ )

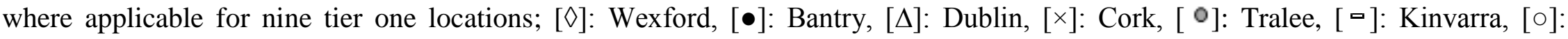
Shannon, [+]: Galway and [•]: Newquay.

Figure 3 Contaminant data $\left(\mu \mathrm{g} \mathrm{kg}^{-1} \mathrm{dw}\right)$ and comparison to assessment criteria (BAC [ $\left.\square\right]$ and EAC [ $\left.\square\right]$ ) (a) for PCBs and (b) for metals

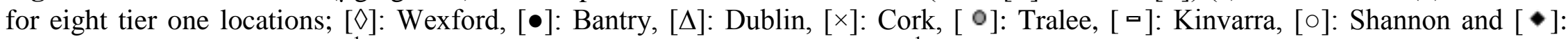
Newquay; * EAC is $80 \mathrm{ug} \mathrm{kg}^{-1}$ for PCB153; ** value for Cork is $21982 \mathrm{ug} \mathrm{kg}^{-1}$ for lead.

Table 1 Summary of literature review for selection of tier one locations including potential pressures, historical elevated concentrations of contaminants and historical biological effects at each of the nine tier one locations.

Table 2 Contaminant data $\left(\mu \mathrm{g} \mathrm{kg}^{-1}\right)$ monitored at eight tier one locations around the Irish coast

Table 3 Comparative table of ranking for each site using contaminant data and ranking by concentration, number of parameters exceeding EAC and number of parameters below BAC

Table 4 Fultons Condition Factor (CF) including standard deviations in parentheses and water temperature and salinity data with significant difference of CF to control site Shannon $\mathrm{p}<0.05\left(^{*}\right), \mathrm{p}<0.001\left(^{* *}\right), \mathrm{p}<0.0001\left(^{* * *}\right)$ and significant difference to control site Galway $\mathrm{p}<0.05\left(^{\dagger}\right), \mathrm{p}<0.001\left(^{\dagger \dagger}\right), \mathrm{p}<0.0001\left({ }^{\dagger \dagger}\right)$

Table 5 Energy Budget and SFG values (mean \pm SE) for Mytilus edulis $(\mathrm{n}=12)$ at nine different tier one locations with significant difference to control site Shannon $\mathrm{p}<0.05\left(^{*}\right), \mathrm{p}<0.001\left(^{* *}\right), \mathrm{p}<0.0001\left(^{* * *}\right)$ and significant difference to control site Galway $\mathrm{p}<$ $0.05\left(^{\dagger}\right), \mathrm{p}<0.001\left(^{\dagger \dagger}\right), \mathrm{p}<0.0001\left(^{\dagger \dagger}\right)$

Table 6 Lethal time at $50 \%\left(\mathrm{LT}_{50}\right)$ data for the stress on stress assay including $95 \%$ confidence intervals $(\mathrm{CI})$ and assessment criteria $\left(\mathrm{R}^{2}\right.$ all significant at $\mathrm{p}<<0.001$ )

Table 7 Best BIOENV analysis showing number of variables $(\mathrm{N})$, degree of variability explained $\left(\mathrm{R}^{2}\right)$, significance level $(\%)$ and predictor variables most important. 



\section{References}

Anderlini, V.C., 1992. The effect of sewage on trace metal concentrations and scope for growth in Mytilus edulis aoteanus and Perna canaliculus from Wellington Harbour, New Zealand. The Science of the Total Environment, 125, 263-288.

Bagenal, T.B.; Tesch, F.W., 1978: Age and growth. In: Bagenal, T. (ed.): Methods for the assessment of fish production in fresh waters (3. ed.). Blackwell Scientific Publications, 365 pp.

Bayne, B.L. 1976 Marine Mussels their ecology and physiology International Biological Programme 10 Cambridge University Press

Buggy, C., Tobin, J.M. 2006a. Spatial distribution of nine metals in surface sediment of an urban estuary prior to a large scale reclamation project. Marine Pollution Bulletin 52, 969-987.

Buggy, C., Tobin, J.M., 2006b. Seasonal and spatial distributions of tributyltin in surface sediment of the Tolka Estuary, Dublin, Ireland. Environmental Pollution, 143, 294-303.

Choiseul, V., Wilson, J.G., Nixon, E. 1998. The distribution of hydrocarbons on the East and South-West Irish coasts and in the Liffey estuary. Biology and Environment: Proceedings of the Royal Irish Academy, 98B, 75-86.

Costello, M.J., Hartnett, M., Mills, P., Mongain, E.O., Collier, L., Johnson, M., Nash, S., Leslie, R., Berry, A., Emblow, C., Collins, A., McCrea, M. 2000. Measurement and modeling of nutrient dynamics of two estuaries in Ireland, Wexford and Cork Harbours, Environmental Protection Agency.

Coughlan, J. 1969. The estimation of filtering rate from the clearance of suspensions. Marine Biology, 2:356-358.

Damiens, G., Gnassia-Barelli, Loque`s, F., Romeo, M., Salbert, V. 2007. Integrated biomarker response index as a useful tool for environmental assessment evaluated using transplanted mussels, Chemosphere, 66, 574-583.

De Zwaan, A. Eertman, R.H.M 1996. Anoxic or Aerial Survival of Bivalves and Other Euryoxic Invertebrates as a useful Response to Environmental Stress- A Comprehensive Review Comparative Biochemistry and Physiology 113C, 2, 299-312.

Duchemin, M.B, Auffret, M., Wessel, N., Fortier, M., Morin, Y., Pellerin, J., Fournier, M. 2008. Multiple experimental approaches of immunotoxic effects of mercury chloride in the blue mussel, Mytilus edulis, through in vivo, in tubo and in vitro exposures. Environmental Pollution, 153, 2, 416-423. 
Eertman, R.H.M., Wagenvoort, A.J., Hummel, H., Smaal, A.C. 1993. "Survival in air" of the blue mussel Mytilus edulis L. as a sensitive response to pollution-induced environmental stress, Journal of Experimental Marine Biology and Ecology, 170, 179-195.

European Commission, 2000. Directive 2000/60/EC of the European Parliament and of the Council of 23 October 2000, establishing a framework for community action in the field of water policy. Official Journal of the European Union L327, 1-72.

European Commission, 2008a. Directive 2008/56/EC of the European Parliament and of the Council of 17 June 2008, establishing a framework for community action in the field of marine environmental policy (Marine Strategy Framework Directive). Official Journal of the European Union L164, 19-40.

Falvey, J.P.H. 1995 An Assessment of the pollution status of inner Tralee Bay Environmental Science MSc. project TCD.

Giltrap, M. 2008. An Integrated Approach to the toxicity Evaluation of Irish Marine Sediment: Chemical Assessment. PhD thesis DIT.

Giltrap, M., Macken, A., Davoren, M., McGovern, E., Foley, B., Larsen, M., White, J., McHugh, B. 2012. Utilising caging techniques to investigate metal assimilation in Nucella lapillus, Mytilus edulis and Crassostrea gigas at three Irish coastal locations. Estuarine, Coastal and Shelf Science xxx

Glynn, D., Tyrrell, L., McHugh, B., Rowe, A., Monaghan, E., Costello, J., McGovern, E. 2001. Trace Metal and Chlorinated Hydrocarbon Concentrations in Shellfish from Irish Waters, Marine Environmental and Health Series, Marine Institute, 10.

Goldberg, E.D. 1975. The mussel watch - a first step in global marine monitoring. Marine Pollution Bulletin 6, 111.

Glynn, D., Tyrrell, L., McHugh, B., Rowe, A., Monaghan, E., Costello, J., McGovern, E. 2001. Trace Metal and Chlorinated Hydrocarbon Concentrations in Shellfish from Irish Waters, Marine Environmental and Health Series, Marine Institute, 10.

Hagger, J.A., Jones, M.B., Lowe, D., Leonard, D.R.P., Owen, R., Galloway, T.S. 2008. Application of biomarkers for improving risk assessments of chemicals under the Water Framework Directive: A case study. Marine Pollution Bulletin, 56, 1111-1118.

Halldórsson, H.P., Svavarsson, J. Granmo, Å. 2005. The effect of pollution on scope for growth of the mussel (Mytilus edulis L.) in Iceland. Marine Environmental Research, 59, 47-64. 
Hartnett, M., Wilson, J. G., Nash, S. 2011. Water quality status and monitoring implications under the water framework directive. Marine Policy, 35, 810-818.

Hellou, J., Law, R. J. 2003. Stress on Stress response of wild mussels, Mytilus edulis and Mytilus trossulus, as an indicator of ecosystem health. Environmental Pollution, 126, 407-416

Kilemade., M., Hartl, M.G.J., Sheehan, D., Mothersill, C., Van Pelt., F.N.A.M, O’ Brien, N.M., O’Halloran, J. 2004. An assessment of the pollutant status of surficial sediment in Cork Harbour in the South East of Ireland with particular reference to polycyclic aromatic hydrocarbons. Marine Pollution Bulletin 49, 1084-1096.

Kilemade., M., M., Hartl, M.G.J., O’Halloran, J., O’ Brien, N.M., Sheehan, D., Mothersill, C., Van Pelt., F.N.A.M 2009. Effects of contaminated sediment from Cork Harbour, Ireland on the cytochrome P450 system of turbot Ecotoxicology and Environmental Safety $72,747-755$

Manley, A.R. 1983. The effects of Copper on the behavior, respiration, filtration and ventilation activity of Mytilus edulis. Journal of the Marine Biological Association of the United Kingdom 63, 205-222.

McBreen, F. and Wilson, J.G. 2005. The Pollution Status of North Dublin Bay. Proceedings of ESAI ENVIRON 2005.

McGovern, E., Cronin, M., Joyce, E., McHugh, B. 2011. An assessment of dangerous substances in Water Framework Directive transitional and coastal waters 2007-2009. Marine Environment and Health Series, 38.

Minchin, D., Stroben, E., Oehlmann, J., Bauer, B., Duggan, C. B. and Keatinge, M., 1996. Biological indicators used to map organotin contamination in Cork Harbour, Ireland. Marine Pollution Bulletin, 32: 188-195.

Moon, T.W., Pritchard, A.W. 1970. Metabolic adaptations in vertically-separated populations of Mytilus californianus, Journal of Experimental Marine Biology and Ecology, 5, 1, 1970, 35-46.

Moore, M.N., Widdows, J., Cleary, J.J., Pipe, R.K., Salkeld, P.N., Donkin, P. Farrar, S.V., Evans, S.V., Thomson, P.E. 1984. Responses of the Mussel Mytilus edulis to Copper and Phenanthrene: Interactive effects, Marine Environmental Research, 14, 167183. 
Moore, M.N., Lowe, D., Koehler, A. 2004. Biological effects of contaminants: Measurement of lysosomal membrane stability. ICES Techniques in Marine Environmental Science 36, 31.

Mubiana, V.K., Blust, R. 2007. Effects of temperature on scope for growth and accumulation of $\mathrm{Cd}, \mathrm{Co}, \mathrm{Cu}, \mathrm{Pb}$ by the marine bivalve Mytilus edulis. Marine Environmental Research, 63, 219-235.

Newell, R.C., Pye, V.I. 1970. Seasonal changes in the effect of temperature on the oxygen consumption of the winkle Littorina littorea (L.) and the mussel Mytilus edulis (L.) Comparative Biochemistry and Physiology, 34, 2, 367-383.

Nortug, T. Børseth, J.F., Olsen, A., Zachariassen, K.E. 1991. Measurements of oxygen consumption in Mytilus edulis during exposure to, and recovery from, high sublethal concentrations of formaldehyde, benzene and phenol. Comparative Biochemistry and Physiology Part C: Comparative Pharmacology, 100, 1-2, 85-87.

O’ Beirn, F.X., Walker, R.L. 1999. Pea Crab, Pinnotheres ostreum Say, 1817, in the Eastern Oyster, Crassostrea virginica (Gmelin, 1971): Prevalence and Apparent Adverse Effects on Oyster Gonad Development. The Veliger, 42, 1, 17-20.

O’ Donnell, G., Joyce, E., O’Boyle, S., McGovern, E., Silke, J. 2008. Pilot Water Quality Monitoring Station in Dublin Bay North Bank Monitoring Station (NBMS) Matsis Project Part 1. Marien Institute, Marine and Environment Health Series, 35.

O' Leary, C., Breen, J. 1998. Seasonal variation of heavy metals in Mytilus edulis, Fucus vesiculosus and sediment from the Shannon estuary. Biology and Environment: Proceedings of the Royal Irish Academy, 98B, 3, 153-169.

Pampanin, D.M., Volpato, E., Marangon, I., Nasci, C. 2005 Physiological measurements from native and transplanted mussel (Mytilus galloprovincialis) in the canals of Venice. Survival in air and condition index. Comparative Biochemistry and Physiology, Part A, 140, 41-52.

Siegel, S., 1956. Nonparametric statistics, The American Statistical Association.

Smaal, A.C., Wagenvoort, A., Hemelraad, J., Akkerman, I. 1991 Response to stress of mussels (Mytilus edulis) exposed in dutch tidal waters,Comparative Biochemistry and Physiology Part C: Comparative Pharmacology, 100, 1-2, 197-200.

Smedes, F. 1999. Determination of total lipid using non-chlorinated solvents. Analyst 124, $1711-1718$. 
Tarrant, H.; Llewellyn, N.; Lyons, A.; Tattersall, N.; Wylde, S.; Moutakitis, G.; Maloney, M.; McKenzie, C. 2005. Endocrine Disruptors in the Irish Aquatic Environment, Environmental Protection Agency, Ireland

Thain, J.E., Vethaak, D.A., Hylland, K. 2008. Contaminants in marine ecosystems: developing an integrated indicator framework using biological-effect techniques ICES Journal of Marine Science Advance Access.

Viarengo, A., Canesi, L., Pertica, M., Mancinelli, G., Accomando, R., Smaal, A.C., Orunesua, M. 1995. Stress on Stress Response: A Simple Monitoring Tool in the Assessment of a General Stress Syndrome in Mussels Marine Environmenlol Research, 39, $245-248$.

Wang, Y., Hu, M., Wong, W.H., Shin, P.K.S., Cheung, S.G. 2011. The combined effects of oxygen availability and salinity on physiological responses and scope for growth in the green-lipped mussel Perna viridis. Marine Pollution Bulletin, 63, $255-261$.

Whitehead, H. 2008. Analyzing Animal Societies: Quantitative methods for vertebrate social analysis

Widdows, J., Phelps, D.K., Galloway, W. 1980-81. Measurement of physiological condition of mussels transplanted along a pollution gradient in Narragansett Bay, Marine Environmental Research, 4, 181-194.

Widdows J., Donkin, P., Evans, S.V., 1987. Physiological Responses of Mytilus edulis During Chronic Oil Exposure and Recovery. Marine Environmental Research 23, 15-32.

Widdows, J., Donkin, P., Page, D. 1989. Combined effects of Structurally Related and Unrelated Toxicants on the Clearance Rate of Mytilus edulis. Marine Environmental Research, 28, 1-4, 543-544.

Widdows , J. and Page, D.S. 1993. Effects of Tributyltin and Dibutyltin on the Physiological Energetics of the Mussel, Mytilus edulis. Marine Environmental Research, 35, 233-249.

Widdows J., Nasci, C., Fossato, V.U. 1997. Effects of Pollution on the Scope for Growth of Mussels (Mytilus galloprovincialis) from the Venice Lagoon, Italy. Marine Environemntal Research, 43, 69-79.

Widdows, J., Staff, F. 1997. Practical procedures for the measurement of scope for growth. Prospect Place, West Hoe, Plymouth, UK: Plymouth Marine Laboratory. 
Widdows J., Donkin, P., F.J. Staff, Matthiessen, P., Law, R.J., Allen, Y.T, Thain, J.E., Allchin, C.R., Jones, B.R. 2002. Measurement of Stress Effects (scope for growth) and contaminant levels in mussels (Mytilus edulis) collected from the Irish Sea. Marine Environmental Research, 53, 327-356.

Widdows, J., Staff, F. 2006. Biological effects of contaminants: Measurement of Scope for Growth in mussels. ICES techniques in Marine Environmental Sciences, 40.

Wilson, J.G., 2003. Diffuse inputs of nutrients to Dublin Bay. Estuarine Coastal and Shelf Science conference proceedings.

Wilson, J., McMahon, R. 1981. Effects of high environmental copper concentration on the oxygen consumption, condition and shell morphology of natural populations of Mytilus edulis L. and Littorina Rudis Maton Comparative Biochemistry and Physiology, 70C, 139-147. 


\begin{tabular}{|c|c|c|c|c|c|c|c|}
\hline Site & GPS & Potential pressures & $\begin{array}{l}\text { Elevated } \\
\text { contaminants in } \\
\text { sediment }\end{array}$ & $\begin{array}{l}\text { Elevated } \\
\text { contaminants in } \\
\text { biota }\end{array}$ & $\begin{array}{l}\text { Elevated } \\
\text { contaminants in } \\
\text { water }\end{array}$ & $\begin{array}{l}\text { Biological } \\
\text { effects }\end{array}$ & Reference \\
\hline $\begin{array}{l}\text { Dublin Bay (Tolka } \\
\text { estuary) }\end{array}$ & $\begin{array}{l}53^{\circ} 21^{\prime} 27.58 \mathrm{~N} \\
6^{\circ} 11^{\prime} 30.31 \mathrm{~W}\end{array}$ & $\begin{array}{l}\text { River Liffey; River Tolka; } \\
\text { Industry; Shipping; Eutrophication } \\
\text { Sewage discharge: Ringsend } \\
\text { WWTP (1, 640,000 PE), } \\
\text { Secondary treatment }\end{array}$ & $\begin{array}{l}\text { TBT, metals } \\
\text { PLI } \\
\text { Metals, OTs, PCBs, } \\
\text { PAHs,HCs }\end{array}$ & $\begin{array}{l}\text { Hydrocarbons } \\
\text { BQI } \\
\text { Metals }\end{array}$ & $\begin{array}{l}\text { Nutrients: DIN and } \\
\text { Phosphate }\end{array}$ & $\begin{array}{l}\text { VTG } \\
\text { Imposex }\end{array}$ & $\begin{array}{l}\text { Wilson, } 2003 \\
\text { O ‘Donnell et al., } 2008 \\
\text { Buggy and Tobin, } 2006 \text { a and b } \\
\text { Choiseul et al., } 1998 \\
\text { McBreen and Wilson, } 2005 \\
\text { Tarrant et al., } 2005 \\
\text { Minchin personal comm., } \\
\text { Giltrap et al., } 2009 \\
\text { Giltrap et al., } 2012 \text { and PhD } \\
\text { thesis 2008 }\end{array}$ \\
\hline Cork harbour & $\begin{array}{l}51^{\circ} 49^{\prime} 53.46 \mathrm{~N} \\
8^{\circ} 18^{\prime} 02.82 \mathrm{~W}\end{array}$ & $\begin{array}{l}\text { Industry (pharmaceutical); } \\
\text { Haulbowline site; Shipping } \\
\text { Sewage discharge: WWTP } \\
\text { 413,000 plant PE, } 323,000 \\
\text { agglomeration PE (Secondary } \\
\text { treatment) }\end{array}$ & PAHs & & & $\begin{array}{l}\text { Cytochrome } \\
\text { P450 (turbot) } \\
\text { Imposex }\end{array}$ & $\begin{array}{l}\text { Kilemade et al., } 2004 \\
\text { Kilemade et al., } 2009 \\
\text { Minchin et al., } 1996\end{array}$ \\
\hline Tralee Bay & $\begin{array}{l}52^{\circ} 16^{\prime} 36.75 \mathrm{~N} \\
9^{\circ} 49^{\prime} 29.62 \mathrm{~W}\end{array}$ & Shipping; Sewage discharge & & $\begin{array}{l}\text { Cd in oysters } \\
\text { Metals }\end{array}$ & & Imposex & $\begin{array}{l}\text { Minchin et al., } 2003 \\
\text { Falvey J.P.H (TCD mod thesis } \\
\text { 1995) }\end{array}$ \\
\hline Kinvarra Bay & $\begin{array}{l}\text { N56.14097 } \\
\text { W008.93758 }\end{array}$ & $\begin{array}{l}\text { Small shipyard;Raw sewage } \\
\text { discharge PE } 850\end{array}$ & & & & & \\
\hline Wexford harbour & $\begin{array}{l}52^{\circ} 20^{\prime} 22.67 \mathrm{~N} \\
6^{\circ} 27^{\prime} 18.37 \mathrm{~W}\end{array}$ & $\begin{array}{l}\text { Eutrophication; Sewage discharge } \\
\text { Shipping; Pigfarm; Landfill run } \\
\text { off } \\
\text { Sewage discharge: } 45,000 \mathrm{PE} \\
(30,000=\text { plant PE, } \\
17,000=\text { agglomeration PE**) } \\
\text { Secondary treatment with NR }\end{array}$ & & & & & $\begin{array}{l}\text { Costello et al., } 2000 \\
\text { (EPA report) }\end{array}$ \\
\hline Bantry Bay & $\begin{array}{l}51^{\circ} 40^{\prime} 50.54 \mathrm{~N} \\
9^{\circ} 27^{\prime} 16.48 \mathrm{~W}\end{array}$ & & Metals, OTs, HCs & & & & $\begin{array}{l}\text { Enterprise Ireland (unpublished } \\
\text { data) }\end{array}$ \\
\hline Galway Bay & $\begin{array}{l}53^{\circ} 14^{\prime} 27.60 \mathrm{~N} \\
9^{\circ} 44^{\prime} 19.19 \mathrm{~W}\end{array}$ & $\begin{array}{l}\text { Sewage discharge:Mutton Island } \\
\text { WWTP (91,600PE) Secondary } \\
\text { treatment }\end{array}$ & & & & & \\
\hline Newquay & $\begin{array}{l}53^{\circ} 09^{\prime} 27.28 \mathrm{~N} \\
9^{\circ} 04^{\prime} 03.84 \mathrm{~W}\end{array}$ & & $\begin{array}{l}\text { Metals, OTs, PCBs, } \\
\text { PAHs, }\end{array}$ & $\begin{array}{l}\text { Metals; OTs; } \\
\text { PCBs,OCs,metals }\end{array}$ & & & $\begin{array}{l}\text { Giltrap et al., } 2008 ; 2009 ; 2011 \\
\text { Glynn et al., } 2001\end{array}$ \\
\hline Shannon & $\begin{array}{l}52^{\circ} 37.670 \mathrm{~N} \\
009^{\circ} 19.930^{\prime} \mathrm{W}\end{array}$ & & Heavy metals & Heavy metals & & & O' Leary and Breen, 1998 \\
\hline
\end{tabular}

**=taken from EPA Urban Waste Water Discharges in Ireland: A Report for the Years 2006 and 2007

http://www.ie.cognis.com/countries/Ireland/en/ 
Table 2

\begin{tabular}{|c|c|c|c|c|c|c|c|c|c|c|c|}
\hline \multirow[b]{2}{*}{ Compound } & \multicolumn{11}{|c|}{ Site concentration $\mathrm{ug} \mathrm{kg}^{-1} \mathrm{dw}$} \\
\hline & Shannon & New Quay & Tolka & Tralee & Cork & Kinvarra & Bantry & Wexford & BAC & EAC & EC \\
\hline PCB28 & 0.059 & 0.183 & 2.382 & 0.147 & 21.72 & 0.160 & 0.590 & 0.140 & 0.750 & 3.200 & \\
\hline PCB52 & 0.294 & 0.277 & 3.157 & 3.537 & $\mathbf{1 5 . 5 5}$ & 0.160 & 1.630 & 0.140 & 0.750 & 5.400 & \\
\hline PCB101 & 0.389 & 0.199 & 13.68 & 2.486 & NA & 0.120 & 1.390 & 0.590 & 0.700 & 6.000 & \\
\hline PCB 118 & 0.406 & 0.144 & 17.94 & 0.367 & 23.18 & 0.210 & 2.150 & 0.670 & 0.600 & 1.200 & \\
\hline PCB 153 & 0.659 & 0.210 & 12.80 & 0.961 & 15.19 & 0.720 & 10.51 & 1.350 & 0.600 & 80.00 & \\
\hline PCB 138 & 0.783 & 0.365 & 11.19 & 0.593 & 14.47 & 0.260 & 2.150 & 0.800 & 0.600 & 15.80 & \\
\hline PCB 180 & 0.194 & 0.188 & 0.554 & 0.147 & 0.400 & 0.180 & 6.390 & 0.140 & 0.600 & 24.00 & \\
\hline Benzo(a)anthracen & & & & & & & & & & & \\
\hline e & 1.370 & 2.86 & 3.070 & 3.270 & 2.590 & NA & 3.270 & 3.140 & 2.500 & 80.00 & \\
\hline Benzo(a)pyrene & 1.370 & 2.86 & 3.070 & 3.270 & 2.590 & NA & 3.270 & 3.140 & 1.400 & 600.0 & \\
\hline Benzo(ghi)perylene & 1.370 & 2.86 & 3.070 & 3.270 & 2.590 & NA & 3.270 & 3.140 & 2.500 & 110.0 & \\
\hline Fluoranthene & 1.920 & 4.000 & 4.290 & 4.580 & 3.630 & NA & 4.580 & 4.400 & 12.20 & 110.0 & \\
\hline Phenanthrene & 2.700 & 5.700 & 6.100 & 6.500 & 5.200 & NA & 6.500 & 6.300 & 11.00 & 1700 & \\
\hline Pyrene & 1.370 & 2.860 & 3.070 & 3.270 & 2.590 & NA & 3.270 & 3.140 & 9.000 & 100.0 & \\
\hline Cadmium & 939.0 & 657.0 & 1032 & 2030 & 795.0 & 727.0 & 735.0 & 593.0 & 960.0 & & 5882 \\
\hline Mercury & 191.0 & 130.0 & 165.0 & 166.0 & 170.0 & 196.0 & 114.0 & 120.0 & 90.00 & & 2941 \\
\hline Lead & 2098 & 1849 & 8631 & 735.0 & 21982 & 1738 & 7307 & 1550 & 1300 & & 8824 \\
\hline p, p'-DDE & 1.266 & 0.625 & 3.43 & 0.638 & 1.851 & 0.879 & 6.290 & 2.850 & 0.63 & & \\
\hline HCB & 0.082 & 0.077 & 0.044 & 0.062 & 0.145 & 0.055 & 1.340 & 0.078 & 0.63 & & \\
\hline BFR-28 & 0.194 & 0.232 & 0.941 & 0.011 & 3.630 & 0.158 & 2.207 & 0.513 & & & \\
\hline$\alpha-\mathrm{HCH}$ & 0.347 & 0.008 & 0.028 & 0.040 & 0.036 & 0.018 & 0.088 & 0.017 & 0.64 & & \\
\hline lindane & 0.406 & 0.298 & 0.393 & 0.164 & 0.109 & 0.060 & 0.208 & 0.199 & 0.97 & & \\
\hline heptachlor & 0.076 & 0.094 & 0.066 & 0.057 & 0.093 & 0.049 & 0.093 & 0.033 & & & \\
\hline
\end{tabular}

NA: Not analysed

Italics: < BAC; normal: > BAC < EAC; bold: > EAC; dw: dry weight; highlighted grey are contaminant levels at all eight sites with missing assessment criteria 
Table 3

\begin{tabular}{cccccccc}
\hline Site & $\begin{array}{c}\text { Overall } \\
\text { contaminant } \\
\text { score }\end{array}$ & $\begin{array}{c}\text { Metals } \\
\text { score }\end{array}$ & $\begin{array}{c}\text { PCB } \\
\text { Score }\end{array}$ & $\begin{array}{c}\text { PAH } \\
\text { Score }\end{array}$ & $\begin{array}{c}\text { Contaminant } \\
\text { mean } \\
\text { ranking }\end{array}$ & $\begin{array}{c}\text { Biomarker } \\
\text { mean } \\
\text { ranking }\end{array}$ & $\begin{array}{c}\text { overall rank } \\
\text { biomarkers+ } \\
\text { contaminant }\end{array}$ \\
\hline Shannon & 18.63 & 106.3 & 19.34 & 1.590 & 5 & 9 & $\mathbf{9 . 5}$ \\
NewQuay & 13.57 & 62.67 & 8.390 & 6.910 & 7 & 4 & $\mathbf{9 . 0}$ \\
Dublin & 4172 & 393.9 & 9778 & 7.950 & 2 & 2 & $\mathbf{3 . 0}$ \\
Tralee & 92.11 & 88.21 & 196.0 & 9.040 & 4 & 4 & $\mathbf{6 . 0}$ \\
Cork & 32037 & 814.2 & 65964 & 5.680 & $\mathbf{1}$ & $\mathbf{8}$ & $\mathbf{5 . 0}$ \\
Kinvarra & 21.95 & 76.18 & 7.340 & 0.000 & 8 & 7 & $\mathbf{1 2}$ \\
Bantry & 373.3 & 234.0 & 707.6 & 9.040 & 3 & 4 & $\mathbf{5 . 0}$ \\
Wexford & 16.61 & 48.32 & 21.72 & 8.350 & $\mathbf{6}$ & $\mathbf{1}$ & $\mathbf{6 . 5}$ \\
Galway & NA & NA & NA & NA & NA & 6 & $\mathbf{.}$ \\
\hline
\end{tabular}

NA: not analysed 
Table 4

\begin{tabular}{|c|c|c|c|c|c|}
\hline Site & $\mathbf{N}$ & $\begin{array}{c}\text { Mean size } \\
\text { range } \\
(\mathrm{mm})\end{array}$ & $\begin{array}{c}\text { Mean Condition } \\
\text { Factor }\end{array}$ & $\begin{array}{c}\text { Water temp } \\
{ }^{\circ} \mathrm{C}\end{array}$ & $\begin{array}{c}\text { Salinity } \\
\%\end{array}$ \\
\hline Bantry & 12 & 42.51 & $0.579(0.14)$ & 15 & 6 \\
\hline Galway & 12 & 43.23 & $0.472(0.13)$ & 15.2 & 30.3 \\
\hline Newquay & 12 & 42.51 & $0.616(0.17)$ & 15.3 & 32.1 \\
\hline Shannon & 12 & 40.17 & $0.568(0.19)$ & 12 & 34 \\
\hline Dublin & 12 & 42.82 & $0.708(0.13)$ & 15 & 26.1 \\
\hline Wexford & 11 & 41.73 & 0.804 (1.08) & 4 & 17 \\
\hline Cork & 12 & 42.72 & $0.765(0.22)$ & 14.9 & 29.8 \\
\hline Tralee & 12 & 42.83 & $0.324(0.10)$ & 15.1 & 32.4 \\
\hline Kinvarra & 12 & 42.83 & $0.792(0.19)$ & 10.4 & 16.5 \\
\hline
\end{tabular}


Table 5

\begin{tabular}{|c|c|c|c|c|c|c|c|c|c|}
\hline Site & Dry weight (g) & Length $(\mathbf{c m})$ & $\begin{array}{c}\text { Clearance } \\
{\text { rate } 1 \mathrm{~h}^{-1}}^{-1} \\
\text { animal }^{-1}\end{array}$ & $\begin{array}{c}\text { Clearance } \\
\text { rate } 1 h^{-1} g^{-1}\end{array}$ & $\begin{array}{c}\text { Consumption } \\
\mathrm{Jg}^{-1} \mathbf{h}^{-1}\end{array}$ & $\begin{array}{c}\text { Assimilation } \\
\mathbf{J g}^{-1} \mathbf{h}^{-1}\end{array}$ & $\begin{array}{c}\text { Oxygen } \\
\text { consumption } \\
\mu \mathrm{Mol} \mathrm{O}_{2} \mathrm{~g}^{-1} \mathrm{~h}^{-1}\end{array}$ & $\begin{array}{c}\text { Respiration } \\
\text { rate } \\
\mathbf{J ~ g}^{-1} \mathbf{h}^{-1}\end{array}$ & $\begin{array}{c}\text { SFG } \\
\mathrm{J} \mathrm{g}^{-1} \mathbf{h}^{-1}\end{array}$ \\
\hline $\begin{array}{l}\text { Wexford } \\
\text { Harbour }\end{array}$ & $0.53 \pm 0.18$ & $41.73 \pm 0.57$ & $0.54 \pm 0.1$ & $1.14 \pm 0 . .2$ & $11.37 \pm 1.99$ & $5.68 \pm 0.99$ & $2.0 \pm 0.49$ & $\dagger^{*} 0.42 \pm 0.09$ & ${ }^{\dagger} 4.75 \pm 1.02$ \\
\hline Bantry Bay & $0.45 \pm 0.03$ & $42.51 \pm 0.39$ & $1.5 \pm 0.11$ & $2.71 \pm 0.27$ & $27.09 \pm 2.68$ & $13.54 \pm 1.29$ & $13.71 \pm 2.44$ & $5.79 \pm 0.65$ & $\dagger^{\dagger} 7.75 \pm 1.39$ \\
\hline Dublin Bay & $0.56 \pm 0.04$ & $42.8 \pm 0.41$ & $1.34 \pm 0.09$ & ${ }^{* * * *} 1.98 \pm 0.08$ & $19.77 \pm 0.84$ & $9.89 \pm 0.42$ & $12.36 \pm 1.21$ & ${ }^{\dagger} 5.5 \pm 0.52$ & ${ }^{*} 4.38 \pm 0.74$ \\
\hline Cork Harbour & $0.59 \pm 0.04$ & $42.72 \pm 0.42$ & $1.12 \pm 0.12$ & $1.72 \pm 0.06$ & $17.18 \pm 0.61$ & $8.59 \pm 0.30$ & & & \\
\hline Tralee Bay & $0.26 \pm 0.02$ & $42.83 \pm 0.52$ & $1.39 \pm 0.06$ & $3.65 \pm 0.20$ & $36.53 \pm 2.0$ & $18.27 \pm 1.0$ & & & \\
\hline Kinvarra Bay & $0.62 \pm 0.04$ & $42.83 \pm 0.52$ & $1.45 \pm 0.18$ & $\dagger^{\dagger *} 2.09 \pm 0.24$ & $20.88 \pm 2.39$ & $10.44 \pm 1.20$ & & & \\
\hline $\begin{array}{c}\text { Shannon } \\
\text { Estuary }\end{array}$ & $0.37 \pm 0.04$ & $40.17 \pm 0.41$ & $1.55 \pm 0.08$ & $3.16 \pm 0.19$ & $31.62 \pm 1.89$ & $15.81 \pm 0.95$ & $27.36 \pm 4.59$ & $5.81 \pm 0.79$ & $10.01 \pm 1.05$ \\
\hline Galway Bay & $0.38 \pm 0.03$ & $43.23 \pm 0.37$ & $1.70 \pm 0.1$ & $3.35 \pm 0.24$ & $33.48 \pm 2.36$ & $16.74 \pm 1.18$ & $12.78 \pm 1.54$ & $3.14 \pm 0.14$ & $13.60 \pm 1.18$ \\
\hline Newquay & $0.47 \pm 0.04$ & $42.51 \pm 0.40$ & $1.47 \pm 0.1$ & $2.51 \pm 0.22$ & $25.08 \pm 2.16$ & $12.54 \pm 1.08$ & $41.73 \pm 12.21$ & $8.92 \pm 0.92$ & $\dagger^{\dagger} 3.62 \pm 1.44$ \\
\hline $\begin{array}{l}\text { BAC } \\
\text { EAC }\end{array}$ & & & & & & & & & $\begin{array}{c}15 \\
5\end{array}$ \\
\hline
\end{tabular}

Significant difference to control site Shannon $\mathrm{p}<0.05\left(^{*}\right), \mathrm{p}<0.001\left(^{* *}\right), \mathrm{p}<0.0001\left(^{* * * *}\right)$; significant difference to control site Galway $\mathrm{p}<0.05\left({ }^{\dagger}\right), \mathrm{p}<0.001\left(^{\dagger \dagger}\right), \mathrm{p}<0.0001\left(^{\dagger \dagger \dagger}\right)$ 
Table 6

\begin{tabular}{ccc}
\hline Site & $\mathbf{L T}_{\mathbf{5 0}}$ & $\mathbf{C I}$ \\
\hline Dublin & 13.3 & $(13.1-13.5)$ \\
Cork & 17.6 & $(17.1-18.1)$ \\
Kinvarra & 12.5 & $(12.2-12.8)$ \\
Wexford & 8.79 & $(8.48-9.12)$ \\
Newquay & 9.59 & $(9.03-10.2)$ \\
Tralee & 9.89 & $(9.75-10.0)$ \\
Galway & 11.4 & $(11.1-11.7)$ \\
Bantry & 10.3 & $(10.1-10.6)$ \\
Shannon & 15.6 & $(15.2-15.9)$ \\
\hline BAC & 10 & \\
EAC & 5 & \\
\hline
\end{tabular}


Table 7

\begin{tabular}{|c|c|c|c|c|}
\hline Biomarker & $\mathrm{N}$ & Rho & Sig $(\%)$ & $\begin{array}{r}\text { Variables } \\
\end{array}$ \\
\hline $\mathrm{CR} 1 \mathrm{~h}^{-1} \mathrm{~g}^{-1}$ & 5 & 0.912 & 1 & Salinity, PCB153, ppDDE, nickel and zinc \\
\hline CR $1 \mathrm{~h}^{-1}$ animal $^{-1}$ & 4 & 0.358 & 90 & Temperature, arsenic, mercury, lead \\
\hline $\mathrm{RR}$ & 2 & 0.904 & 31 & Temperature, cadmium \\
\hline SFG & 1 & 0.285 & 94 & Mercury \\
\hline SOS & 4 & 0.194 & 98 & Copper, arsenic, mercury, lead \\
\hline
\end{tabular}


Figure 1 (a)

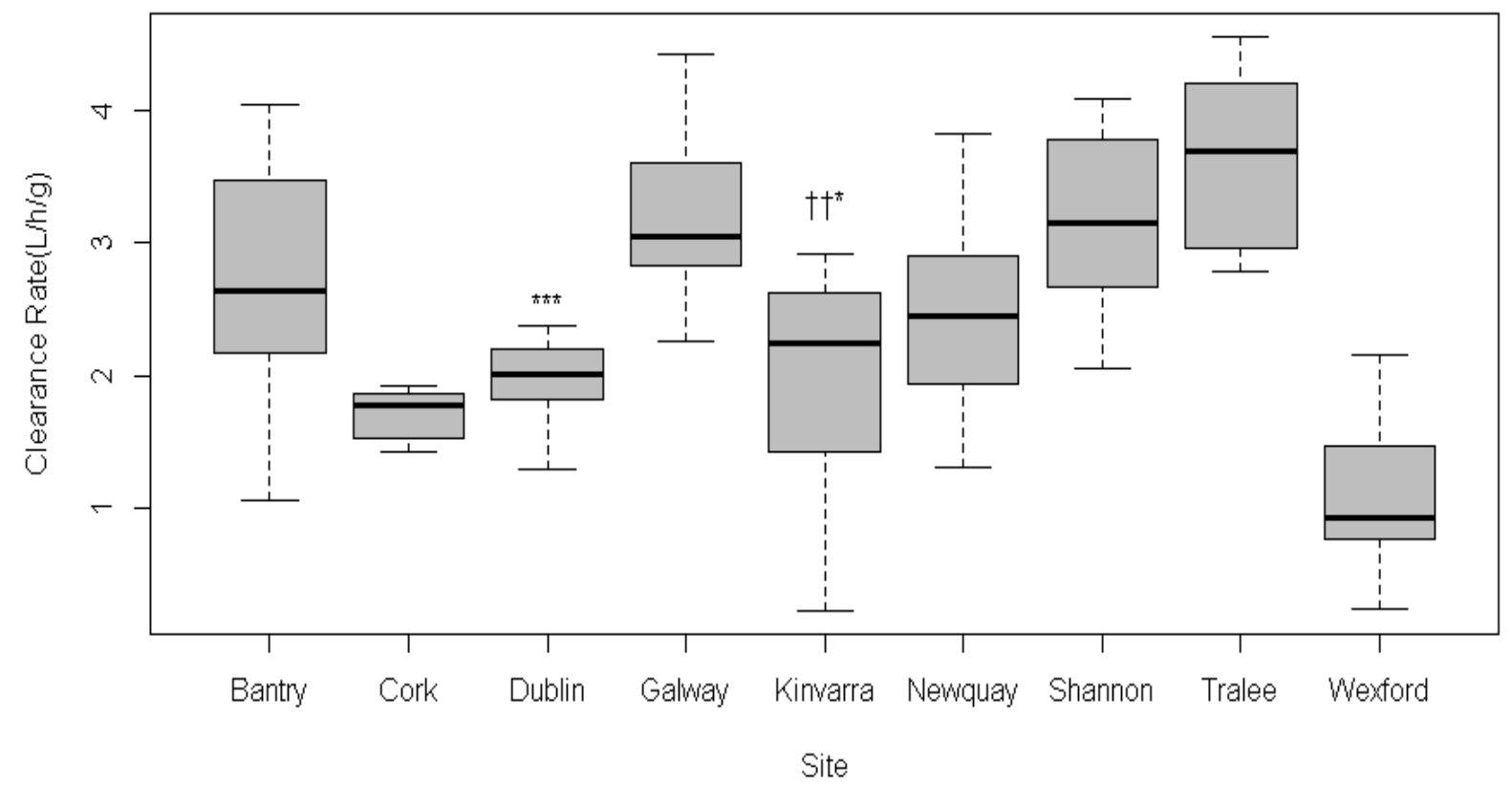

(b)

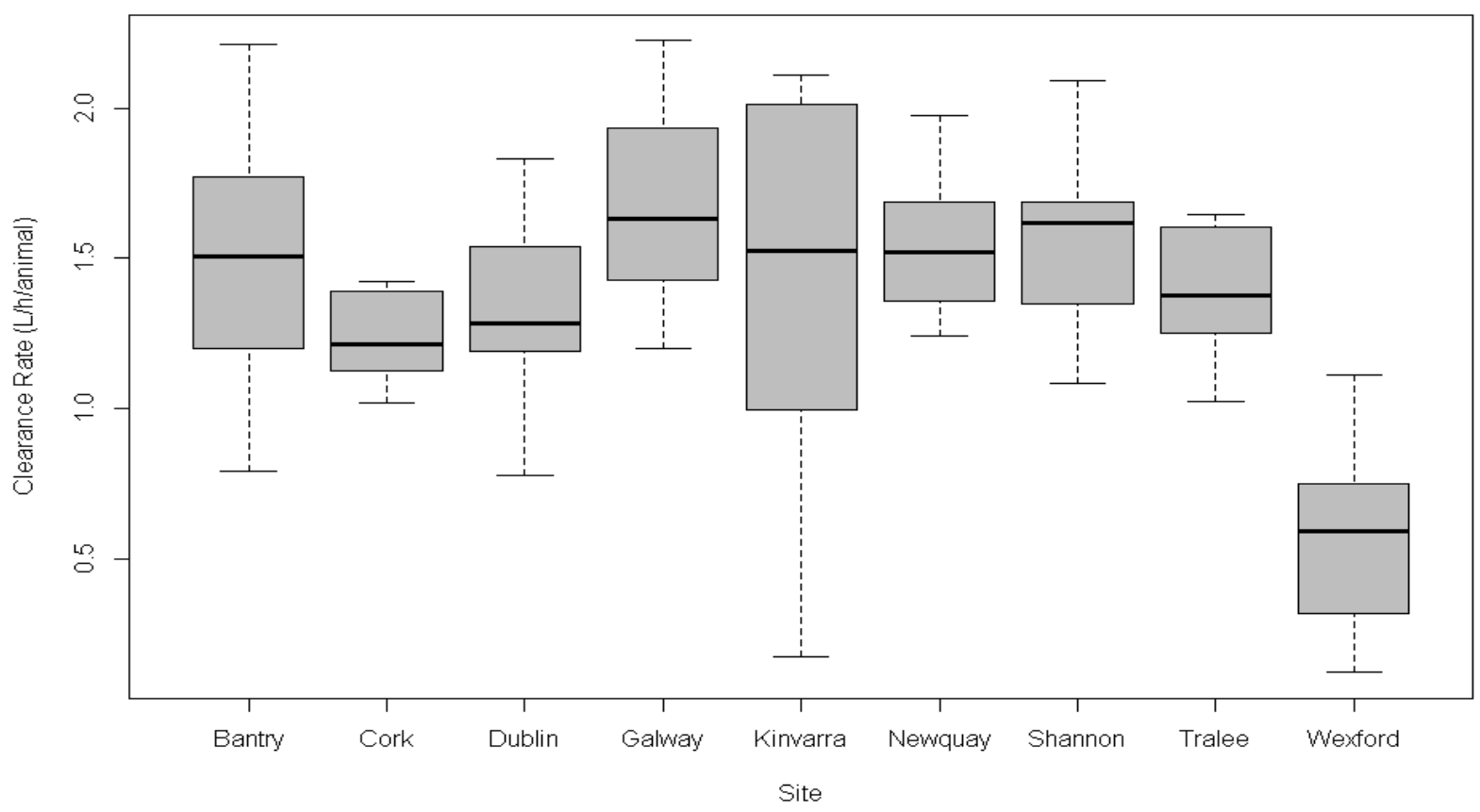


Figure 2

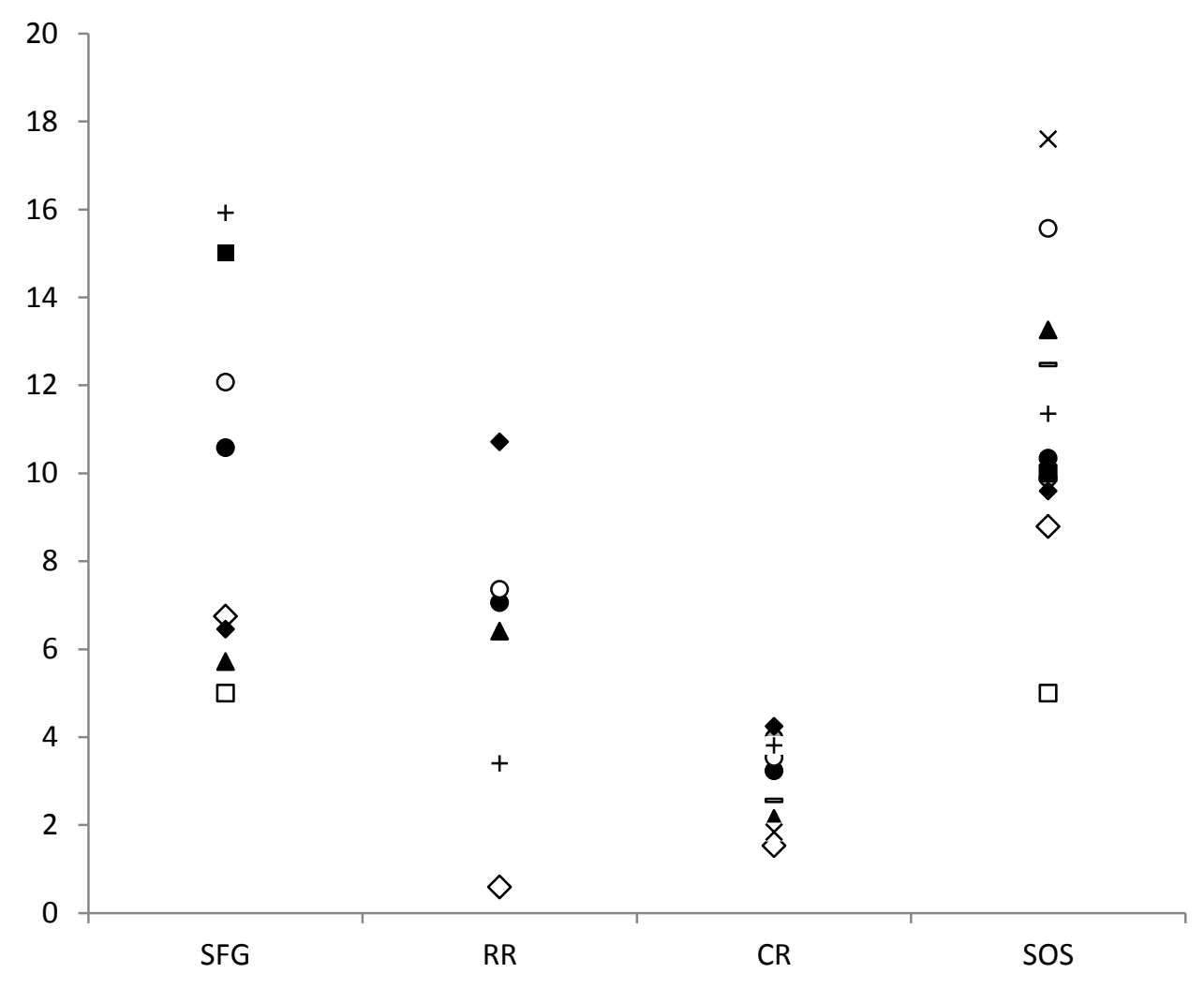


Figure 3 (a)

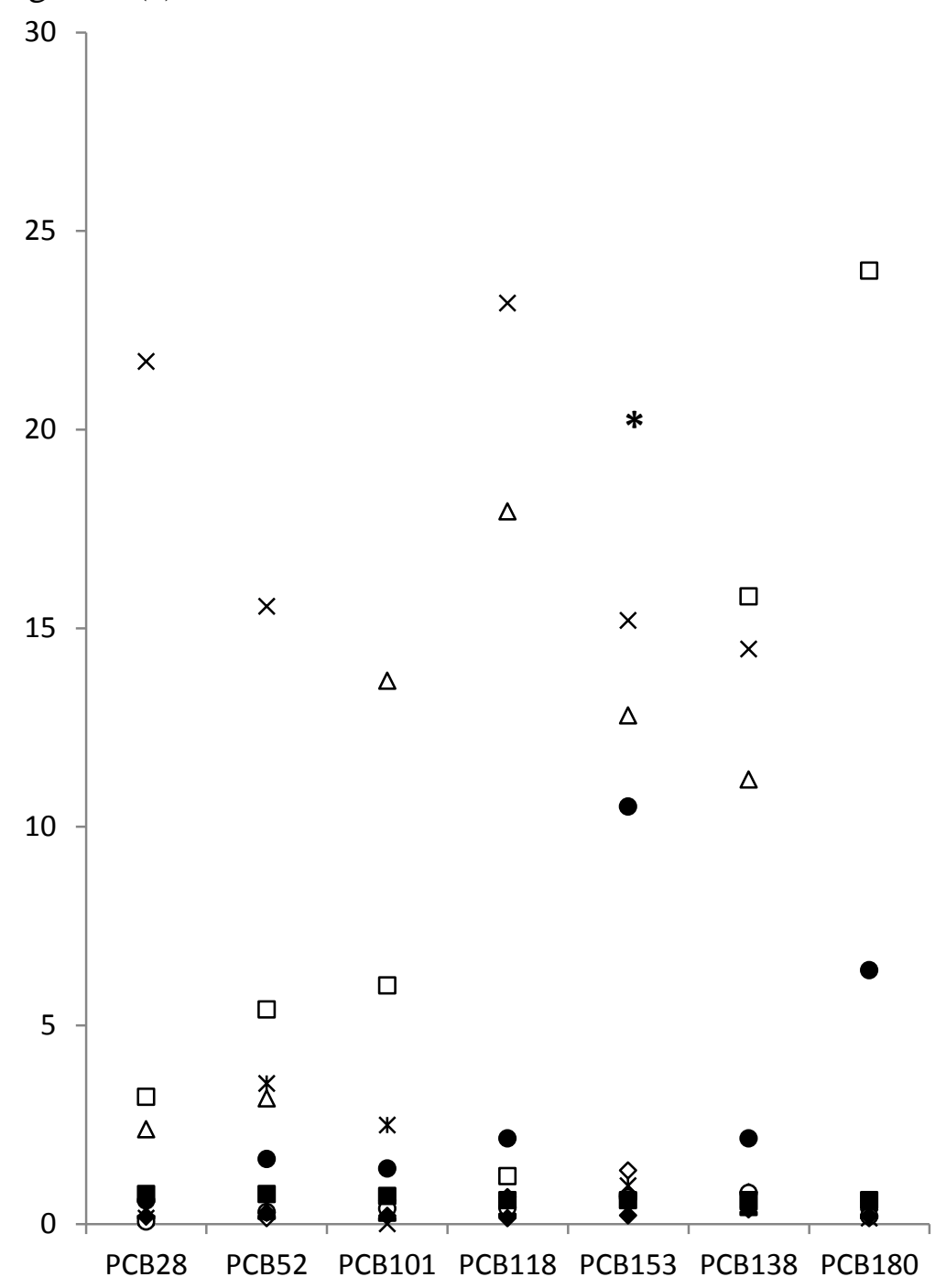

(b) 


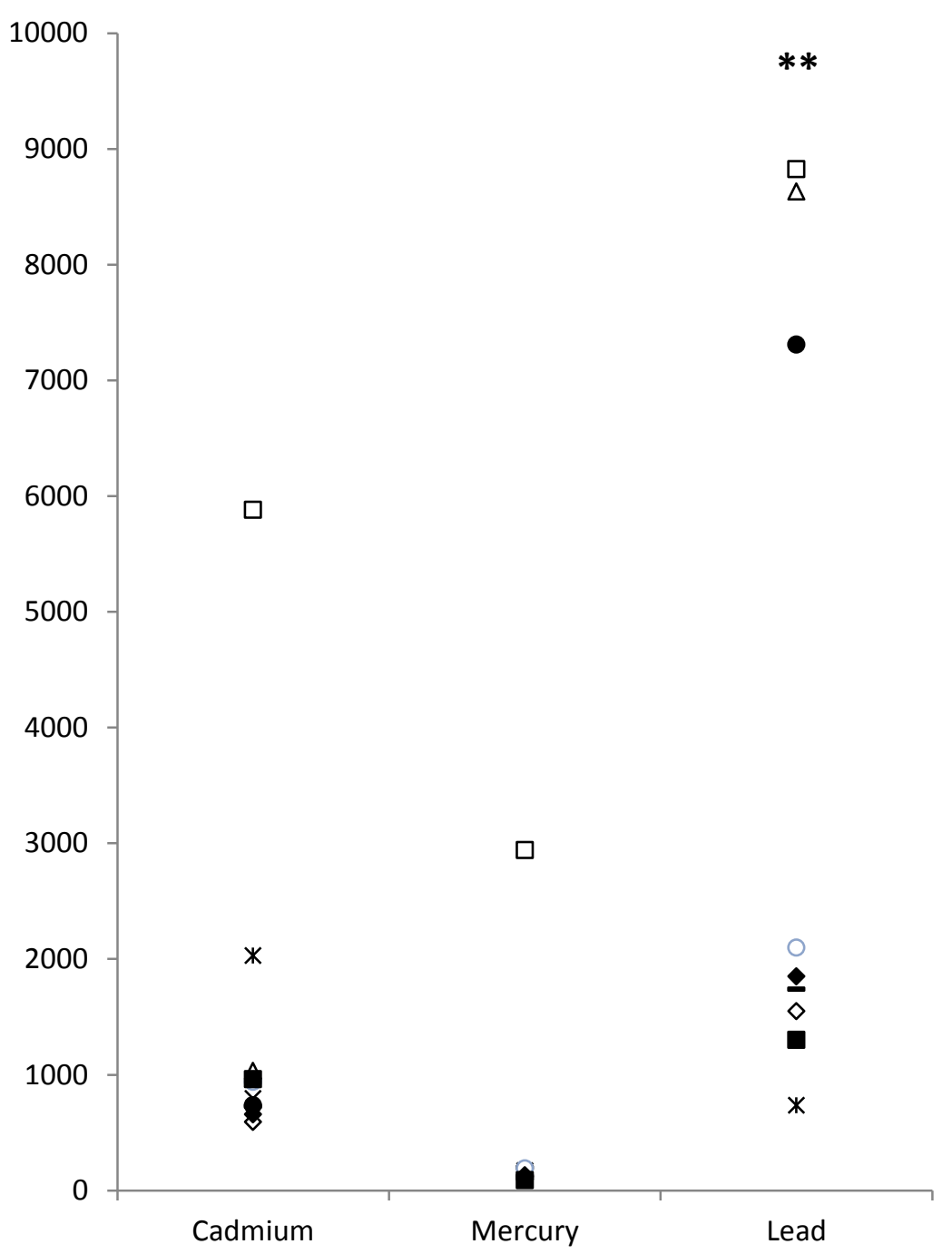

